DOI: 10.18468/letras.2017v7n1.p113-136

\title{
DE ÁGUAS E DE MEMÓRIAS: CORPOS FEMININOS QUE SE ESCREVEM NA FICÇÃO DE CONCEIÇÃO EVARISTO ${ }^{1}$
}

\author{
Jacob dos Santos Biziak ${ }^{2}$
}

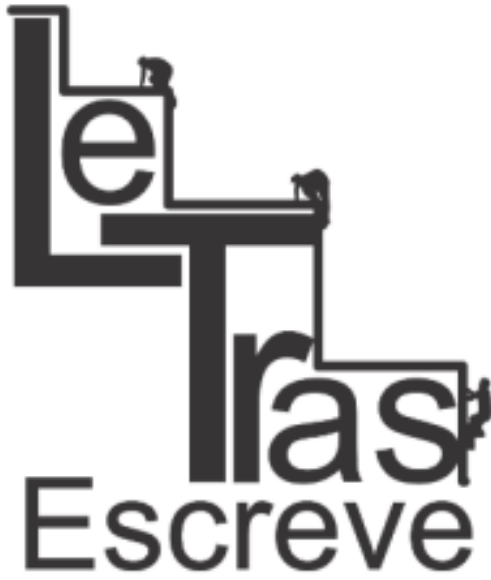

(ISSN 2238-8060)
Negras mulheres, suspendendo às tetas

Magras crianças, cujas bocas pretas

Rega o sangue das mães:

Outras moças, mas nuas e espantadas,

\footnotetext{
${ }^{1}$ Artigo desenvolvido dentro do âmbito de pesquisa de pós doutorado pela USP de Ribeirão Preto (sob supervisão da Professora Livre Docente Lucília Abrahão e Souza); pesquisador membro do E-L@DIS: Laboratório Discursivo (FFCLRP/USP), em que coordena o grupo de estudos "Gêneros sexuais e discurso"; coordenador e pesquisador do G.E.Di (Grupo de Estudos do Discurso, do IFPR, campus Palmas) - Parte das reflexões aqui desenvolvidas tiveram início na aula de encerramento do componente curricular "Gêneros sexuais, discurso e literatura", ofertada como optativa ao acadêmico do curso de Letras do IFPR, campus Palmas. Portanto, dedico este trabalho à primeira turma que frequentou esses encontros durante os sábados pela manhã do segundo semestre de 2016.

2 Instituto Federal do Paraná, IFPR, Campus Palmas, Colegiado de Letras, Palmas, Paraná, Brasil - jacob.biziak@ifpr.edu.br
}

https://periodicos.unifap.br/index.php/letras

Macapá, v. 7, n. I, Io semestre, 2017. 
No turbilhão de espectros arrastadas,

Em ânsia e mágoa vãs!

(Castro Alves, "Navio negreiro")

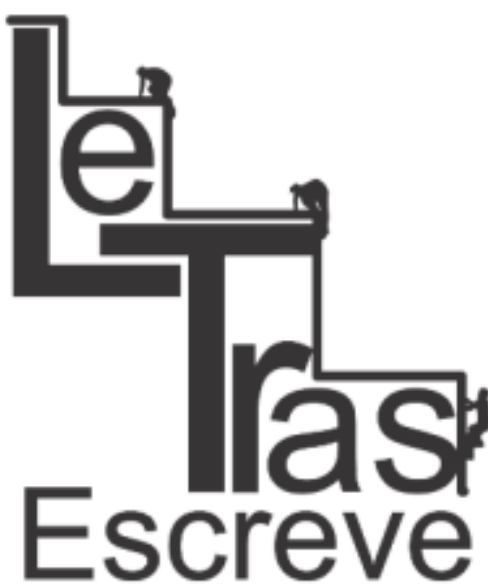

(ISSN 2238-8060)

Na perspectiva do caminho aberto por Pêcheux (1997, p. 146), toda enunciação só pode existir a partir de um posicionamento dentro da ideologia. Dessa forma, os discursos vão sendo atualizados e valorados à medida que representam formas-sujeito que só podem existir porque a ideologia permite isso. Esta, portanto, cria um efeito de evidência por meio do qual os sujeitos acreditam que "as coisas não poderiam ser de outro jeito"; em outras palavras, não existe naturalidade, mas construções discursivas nas e pelas quais o caráter material do sentido se faz existir. Logo, por "caráter material", Pêcheux problematiza o funcionamento discursivo, de forma que as significações só existem porque estão dentro da história, expressando pontos de vista que estão longe de serem "naturais".

Ou seja, não há sentido que não seja ideológico, expressando existências que só são possíveis a partir de interpretações sobre a realidade histórica e a social. Portanto, este artigo não foge disso e expressa um desejo do analista que o assina. Aqui, então, o nosso posicionamento parte do pressuposto de que os corpos, dentro da escrita literária e artística, não podem ser lidos a partir de qualquer perspectiva de neutralidade, uma vez que esta expressa um esquecimento típico da ação da ideologia (Orlandi, 2011) e não um fato irrefutável. Dessa maneira, queremos, justamente, aproveitar que não há sentido fora da ideologia para deslocar reflexões de locais considerados "senso comum", "óbvios", para outros, em que novas possibilidades de se vislumbrar as construções semânticas sejam possíveis. Para além do certo e do errado, nosso interesse é observar o 
deslocamento do sentido entre os mais diversos posicionamentos sobre as realidades em que estamos inseridos e em que "fazemos sentido":

A condição da linguagem é a incompletude. Nem sujeitos, nem sentidos estão completos, já feitos, constituídos definitivamente. Constituem-se e funcionam sob o modo do entremeio, da relação, da falta, do movimento. Essa incompletude atesta a abertura do simbólico, pois a falta é também o lugar do possível.

Entretanto, não é porque o processo de significação é aberto que não seria regido, administrado. Ao contrário, é pela sua abertura que ele também está sujeito à determinação, à institucionalização, à estabilização e à cristalização. (...) Ao dizer, o sujeito significa em condições determinadas, impelido, de um lado, pela língua e, de outro, pelo mundo, pela sua experiência, por fatos que reclamam sentidos, e também por sua memória discursiva, por um saber/poder/dever/dizer, em que os fatos fazem sentido por se inscreverem em formações discursivas que representam no discurso as injunções ideológicas. (Orlandi, 2011, p. 50-51)

Graças às reflexões iniciadas por Pêcheux (1997), dentro do âmbito da Análise do Discurso Francesa, alguns conceitos tornaramse fundamentais para o estudo das mais diversas textualidades. No nosso caso, é fundamental entendermos o que o autor apresenta como "sujeito". Este não se confunde com a ideia de "indivíduo", externo ao texto, nem simplesmente com a de "autor pessoa" ${ }^{3}$, empírico. A partir da enunciação, diversas "formas-sujeito" podem ser atualizadas e assumidas, de maneira que não se pode confundir o indivíduo externo ao texto com aquele que se constrói por meio dos discursos, estabelecendo alianças e rupturas entre estes. Mais que isso,

\footnotetext{
${ }^{3}$ Apesar de trazer um outro ponto de vista sobre a ideia de "sujeito", não podemos nos esquecer de que Bakhtin, dentro daquilo que alguns autores nomeiam como Análise Dialógica do Discurso, já traz a distinção entre "autor pessoa" e "autor criador" como instrumental de estudo dos textos.
} 


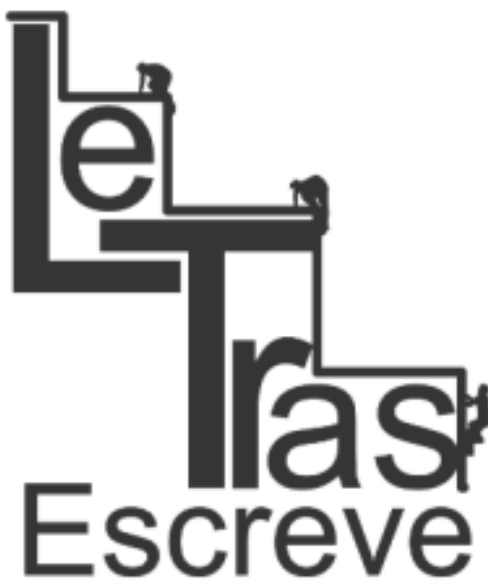

(ISSN 2238-8060) qualquer existência fora das textualidades - e portanto, fora da história e da ideologia - não nos interessa enquanto analistas do discurso. Se há existência, essa só pode ganhar corpo pelo funcionamento textual e discursivo, pagando o preço por isso e, também, vivendo a poética disso. Uma consequência, por exemplo, é que um mesmo enunciador, ao longo de uma construção textual, pode assumir diferentes formas-sujeito que vão - pela relação entre si, com a língua e com a memória - elaborando sentidos.

A expressão "sentido", dentro de todo o seu alcance semântico, pode apontar para a (des)construção de um corpo que "sente", já que, provido de "cinco sentidos" na relação da subjetividade com a realidade que Ihe cerca, permite a reelaboração constante da experiência. Logo, esta se processa pelo movimento deslizante dos significantes no processo de escritura psíquica ${ }^{4}$ dentro de condições de produção históricas. Assim, pelo processo de rememoração, a experiência vive a dialética de ser a mesma e diferente, já que reformulada a cada retomada do vivido. Há um corpo que (re)elabora e (des)constrói significados, dando texturas, cores, aromas aos discursos; mas somente porque existe na história e na ideologia.

No trecho do famoso poema "Navio negreiro" escolhido como epígrafe para este nosso trabalho, temos a representação de corpos femininos e negros que sofrem as dores da escravidão. A partir de uma rápida leitura, podemos ir construindo uma hipótese a respeito do sentido, dado que a experiência existencial desses corpos, dentro do espaço claustrofóbico e de violência do navio, é representada pelos termos "Magras crianças", "sangue das mães", "nuas e espantadas", "turbilhão de espectros arrastadas", "ânsia e mágoa vãs". A escolha do léxico autoriza uma interpretação na qual a banalização

\footnotetext{
${ }^{4}$ Uma interessante e importante reflexão sobre isso encontra-se em "Freud e a cena da escritura", de Derrida (1971).
} 


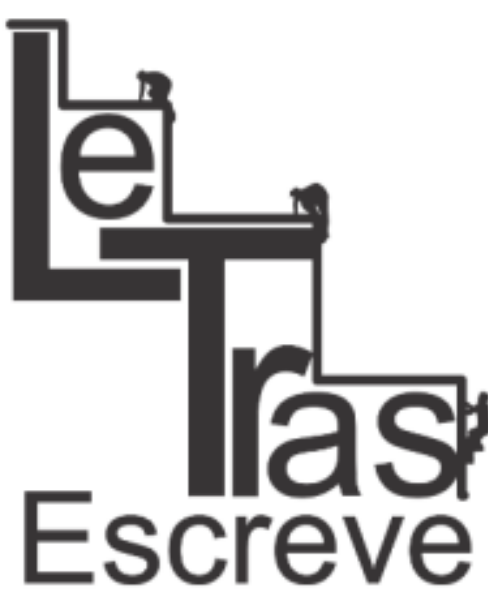

(ISSN 2238-8060)

da vida, bem como o sadismo do dominador, predominam sobre o corpo negro de mulheres que sangram e sentem algo que parece não interessar a ninguém ali. Ao mesmo tempo, a enunciação, em um primeiro momento, assume uma perspectiva de denúncia a respeito dos males sofridos pela população escrava em direção ao Brasil.

No entanto, devemos nos atentar para um problema: tal enunciação é elaborada a partir de uma construção linguística, por exemplo, que não se aproxima da realidade dos corpos ali representados. Ao contrário, entre as escolhas linguísticas do enunciador e as vidas representadas por ele, há diferenças que não podem ser esquecidas, já que são uma construção textual - em tom declamatório - que atualiza discursos sobre a escravidão, mas de fora da vivência dos "outros", os escravos. A visão do mesmo, marcada em "bom português" (a ironia da nomeação da língua, "portuguesa", diante das vidas representadas, em risco de perda de nome, de identidade: são africanas, africanas, apátridas?), norma "cultíssima", metrificada aos moldes da poesia europeia considerada cânone. Isso não necessariamente diminui a qualidade estética do texto, mas desvela um caráter, ainda, dominador, "de fora", que atua como um espectador privilegiado, mas não de corpo e voz "negra".

Assim, pela análise linguística da textualidade que atualiza discursos históricos, o posicionamento da enunciação mostra a impossibilidade de ser neutro, ainda que, talvez, dotado de "boa intenção" (não por acaso, talvez, o senso comum diga que "delas, o inferno está cheio", ainda que seja o inferno denunciado pela enunciação de "Navio negreiro").

Portanto, ao mesmo tempo em que o famoso poema cuja autoria é atribuída a Castro Alves, "poeta dos ${ }^{5}$ escravos", produz alian-

\footnotetext{
${ }^{5}$ Aqui, é interessante notar como a preposição "de" nos permite perceber sentidos que se
} https://periodicos.unifap.br/index.php/letras Macapá, v. 7, n. I, Io semestre, 2017. 


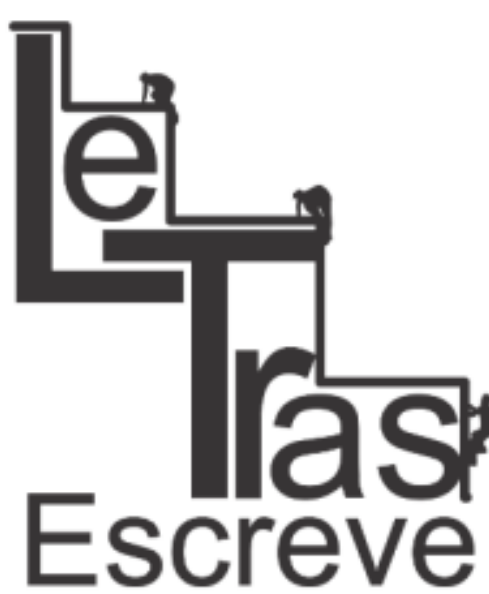

(ISSN 2238-8060)

ças com os discursos de denúncia dos horrores vividos pelos corpos negros na escravidão, cria, também, rupturas com estes mesmos discursos, já que a enunciação que textualiza o poema desnuda um posicionamento de dominador, marcadamente europeu. Não podemos nos esquecer da influência, enquanto memória discursiva, sobre a obra de Castro Alves: Victor Hugo, poeta francês. Dessa forma, o tom de denúncia que torna famoso "Navio negreiro" pode ser visto sob nova luz, descontruindo algumas verdades construídas pela crítica literária ao longo de anos; de forma que esta, também, por meio disso, firma seu posicionamento discursivo sobre a poesia aqui brevemente analisada. Esse exercício de leitura que estamos realizando, até o momento, não tem a pretensão de diminuir o valor social dado ao poema, mas de evidenciar como o sentido desliza à medida que pontos de vistas diferentes são projetados sobre as textualidades.

Além disso, a leitura convocada sobre Castro Alves servirá de interdiscurso ao que pretendemos analisar no conto Olhos d'água, de Conceição Evaristo (2016), presente na coletânea homônima, ganhadora do prêmio Jabuti, em 2016, na modalidade conto. A escritora carioca possui como uma das características mais marcantes de seu trabalho ficcional a representação do cotidiano de personagens negras, pobres, em especial, femininas, mas de um posicionamento discursivo diferente do assumido no poeta "condoreiro" 6 .

deslocam. Afinal, qual sentido se (não) fixa: posse; aquele que surge em função dos escravos; aquele que dá voz aos escravos; aquele que tem origem pelos escravos? Nossos compêndios escolares de literatura, marcadamente os do Ensino Médio, pecam ao não trazerem problematizações como essa e que se somam a outras questões, como a quase inexistência das literaturas africanas no currículo, mesmo de grandes universidades. Assim, qual o sentido em se falar, nessas condições de produção, de um "poeta dos escravos"?

${ }^{6} \mathrm{O}$ uso das aspas, neste artigo, possui intenção semelhante ao convocado por Derrida (1971) ao longo de sua obra: suspender significados para os pensar em novos contextos. Portanto, elas podem se tornar importantes operadores de leitura. Sendo assim, a partir de nossa reflexão, ser "condoreiro" pode revelar outros sentidos: como o de denúncia, mas feita de longe, com distanciamento, não só o caráter de "visão ampla" comumente elaborado por parte da crítica literária brasileira. Qual seria a enunciação de "Navio ne-

https://periodicos.unifap.br/index.php/letras

Macapá, v. 7, n. I, Io semestre, 2017. 


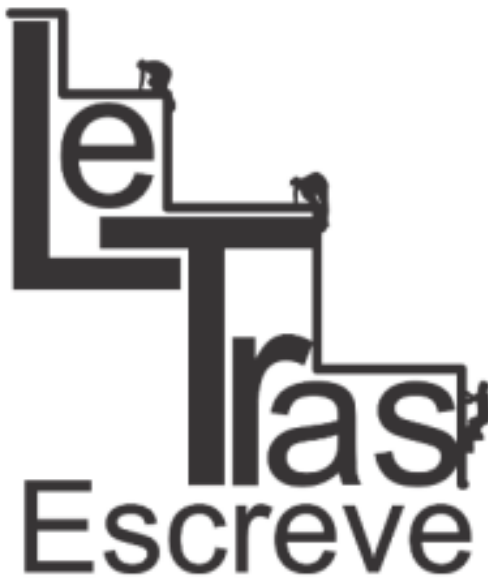

(ISSN 2238-8060)
O corpo textualizado na ficção de Evaristo é negro, mas também pobre e feminino. Isso é importante porque ajuda a tentar compreender os deslocamentos de sentidos operados pela atualização discursiva da opressão vivida dentro de diferenças que são de gênero, mas também de classe social e étnicas. A construção da identidade, portanto, problematiza-se à medida que mostra a complexidade e a precariedade das formas-sujeito: afinal, temos sujeitos que existem por sobreposição de camadas de valores sociais e que, ao mesmo tempo, parecem se perguntar, afinal, o que são, o que significam. ${ }^{7}$ É o corpo negro, feminino e pobre, em "Olhos d'água", que enuncia e se representa, de maneira que, entre os sujeitos representados no conto (mãe e filha mais velha) e o responsável pela enunciação, vão se estabelecendo relações que permitem que o sentido seja elaborado por meio da memória individual e da histórica, já que o que se sente não está fora do seu aspecto material, ideológico.

O estudo discursivo do conto, então, acabou convocando o conceito de interseccionalidade, apresentado por Kimberle Crenshaw (2004):

Meu objetivo é apresentar uma estrutura provisória que nos permita identificar a discriminação racial e a discriminação de gênero, de modo a compreender melhor como essas discriminações operam juntas, limitando as chances de sucesso das mulheres negras. (...) A questão é reconhecer que as experiências das mulheres negras não podem ser enquadradas separadamente nas categorias da discriminação racial ou da discriminação de gênero. Ambas as categorias precisam ser ampliadas para que possamos

greiro" de outra perspectiva: não de longe, "ampla", mas "diminuída", de perto, de dentro do navio?

${ }^{7}$ Stuart Hall (2006) debate as peculiaridades das leituras feitas sobre as identidades na chamada pós-modernidade. Segundo o autor, elas passam a exigir compreensões mais complexas porque não se miram mais os sujeitos como estáveis e centrados, mas como processos intermináveis de elaboração, sujeitos às mais diversas intersecções. No caso do conto de Conceição escolhido como corpus deste estudo, há um corpo negro, mas também feminino e pobre. 


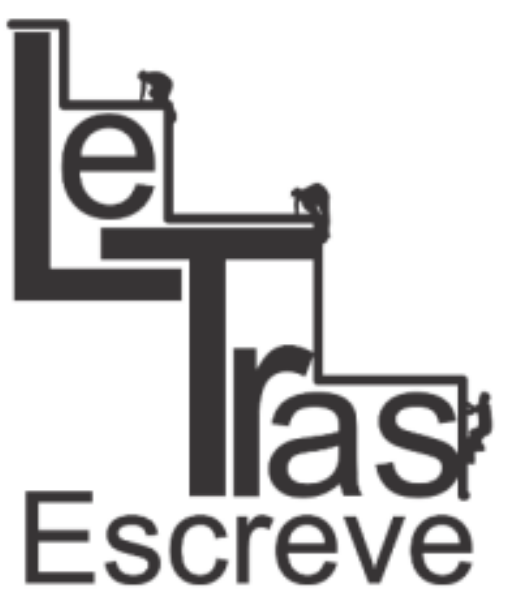

(ISSN 2238-8060) abordar as questões de interseccionalidade que as mulheres negras enfrentam. (...) Assim, tanto as questões de gênero como as raciais têm lidado com a diferença. O desafio é incorporar a questão do gênero à prática dos direitos humanos e a questão racial ao gênero. Isso significa que precisamos compreender que homens e mulheres podem experimentar situações de racismo de maneiras especificamente relacionadas ao seu gênero. As mulheres devem ser protegidas quando são vítimas de discriminação racial, da mesma maneira que os homens, e devem ser protegidas quando sofrem discriminação de gênero/racial de maneiras diferentes. Da mesma maneira, quando mulheres negras sofrem discriminação de gênero, iguais às sofridas pelas mulheres dominantes, devem ser protegidas, assim quando experimentam discriminações raciais que as brancas frequentemente não experimentam. Esse é o desafio da interseccionalidade. (p. 8-9)

O longo trecho acima citado justifica-se uma vez que permite o entendimento de que, na análise discursiva do processo de textualização engendrado no conto de Conceição Evaristo, no que diz respeito à construção do corpo da protagonista, tanto aspectos étnicos quanto de gênero devem ser atentados. Estes estabelecem, entre si, relações de conciliação e de enfrentamento que só podem ser lidos dentro de condições de produção que lhes são específicas. Por isso, devemos ter muito cuidado ao ler, comparativamente, a representação do negro em autores de diferentes contextos históricos e ideológicos que, por seu turno, serão recebidos em situações também específicas ${ }^{8}$.

O conto Olhos d'água (2016, p. 15) apresenta-se à leitura por meio da construção de uma enunciação que assume uma voz autodiegética - segundo a nomenclatura de Genette (s.d.) - ocupada em,

\footnotetext{
${ }^{8}$ Como, por exemplo, a sala de aula brasileira do século XXI. No entanto, tal problemática pode se converter em vantagem, dependendo do trabalho realizado pela formação do nosso jovem leitor.
} 
desde o início, recuperar uma memória de algo ocorrido há anos. Chama a atenção, através da observação do léxico escolhido, o tom fortemente elaborado de certa culpa que se prolonga às raias da violência, de acusação consigo mesma. Trata-se da voz da filha que se pergunta, afinal, qual seria a cor dos olhos da mãe; culpando-se por esquecer de algo, aparentemente, tão óbvio e fundamental:

Uma noite, há anos, acordei bruscamente e uma estranha pergunta explodiu de minha boca. De que cor eram os olhos de minha mãe? Atordoada custei reconhecer o quarto da nova casa em que estava morando e não conseguia me lembrar como havia chegado até ali. $\mathrm{E}$ a insistente pergunta, martelando, martelando... De que cor eram os olhos de minha mãe? Aquela indagação havia surgido há dias, há meses, posso dizer. Entre um afazer e outro, eu me pegava pensando de que cor seriam os olhos de minha mãe. E o que a princípio tinha sido um mero pensamento interrogativo, naquela noite se transformou em uma dolorosa pergunta carregada de um tom acusatório. Então, eu não sabia de que cor eram os olhos de minha mãe? (Evaristo, 2016, p. 15, grifos nossos)

Na abordagem teórica escolhida para este trabalho, a memó(ISSN 2238-8060) ria é produzida sob dois aspectos (Orlandi, 2011, p. 45): arquivo (a memória institucionalizada) e o interdiscurso (a memória constitutiva); de forma que a possibilidade de interpretação se constrói entre um e outro, regulada pela intervenção da história, que dá espessura à linguagem. Logo de começo, então, lemos a espessura material dos significantes que vão sendo apresentados à leitura ao longo do início do conto. O tom de culpa e denúncia do absurdo de se esquecer a cor dos olhos da mãe só é legível dentro da opacidade histórica, em que a figura materna recebe valoração específica. Dessa forma, esquecer-se de algo da mãe é algo passível de culpabilização. Assim, o 


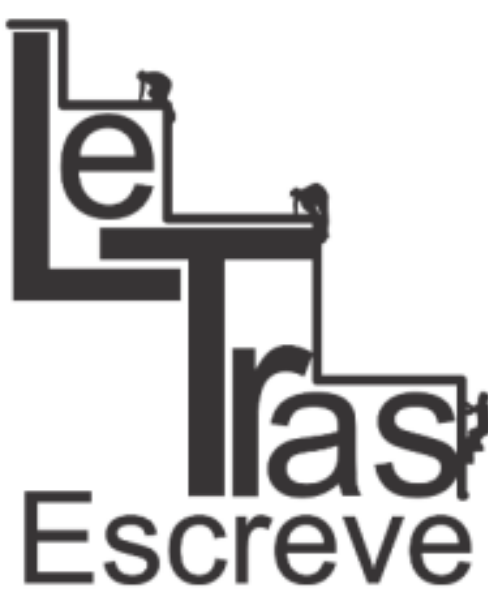

(ISSN 2238-8060)

enunciador começa a se identificar em uma forma-sujeito - filha passível do horror da culpa - que só pode ter acesso à parte do que diz porque "Ele é sujeito à língua e à história (...). Ele é assim determinado, pois se não sofrer os efeitos do simbólico, ou seja, se ela não se submeter à língua e à história ele não se constitui, ele não fala, não produz sentidos" (Orlandi, 2011, p. 46).

Ao mesmo tempo em que tenta produzir rememoração, a enunciadora - já que temos uma voz que se identifica ao feminino sofre efeitos dos esquecimentos (Pêcheux, 1997): o um, ideológico, pelo qual "temos a ilusão de ser a origem do que dizemos, quando, na realidade, retomamos sentidos preexistentes" (Orlandi, 2011, p. 33); o dois, da enunciação, que funciona "de tal modo que pensamos que o que dizemos só pode ser dito com aquelas palavras e não com outras, que só pode ser assim" (ibidem, p. 33). Logo, entre mundo, realidade, pensamento e sujeito, não há naturalidade; mas, sim, toda uma regulação que mostra o quanto a maneira de enunciar não é indiferente aos sentidos.

No caso do conto, a enunciadora sofre efeitos necessários dos esquecimentos, justamente para que possa dizer algo. Por um lado, retoma sentidos preexistentes sobre a posição que julga ocupar enquanto filha e, principalmente, em relação ao corpo da figura materna, de cujos olhos se esqueceu. Por outro lado, a sintaxe e o léxico escolhidos reforçam a posição ideológica que a enunciadora assume enquanto forma-sujeito: diante da perda da recordação dos olhos da mãe, a única possibilidade que parece acenar é a de dor, de culpa, até de castração ${ }^{9}$. Dessa forma, a singularidade da narração só pode

\footnotetext{
${ }^{9}$ Em certa medida, parece que elementos da teoria psicanalítica seriam bem interessantes para este artigo; no entanto, optamos por um recorte teórico pautado somente na análise do discurso de linha francesa, já que nosso intento é o estudo da relação entre língua, história e ideologia sobre a questão da construção discursiva do corpo negro. Além disso, a teoria psicanalítica, para ser aplicada ao estudo de um conto como o escolhido
}

https://periodicos.unifap.br/index.php/letras

Macapá, v. 7, n. I, Io semestre, 2017. 
ser lida na relação com o que já está em processo nos discursos que circulam na formação ideológica. A enunciadora em questão faz entrada nisso ao assumir uma posição diante da língua e da história, ainda que pagando o preço de se esquecer, necessariamente, disso. Ou seja, não há dizer que pode ser neutro, mas somente marcado pela sensação de neutralidade:

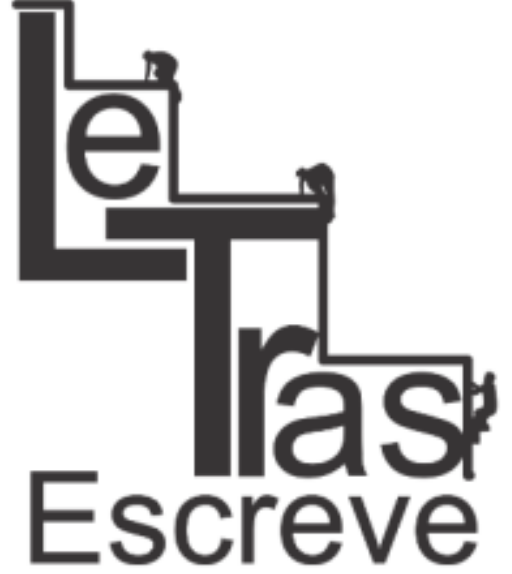

(ISSN 2238-8060)
Quando nascemos os discursos já estão em processo e nós é que entramos nesse processo. Eles não se originam em nós. Isso não significa que não haja singularidade na maneira como a língua e a história nos afetam. Mas não somos o início delas. Elas se realizam em nós em sua materialidade. Essa é uma determinação necessária para que haja sentidos e sujeitos. Por isso é que dizemos que o esquecimento é estruturante. Ele é parte da constituição dos sujeitos e dos sentidos. As ilusões não são "defeitos", são uma necessidade para que a linguagem funcione nos sujeitos e na produção de sentidos. Os sujeitos "esquecem" que já foi dito - e este não é um esquecimento voluntário - para, ao se identificarem com o que dizem, se constituírem em sujeitos. É assim que suas palavras adquirem sentido, é assim que eles se originassem neles e é assim que sentidos e sujeitos estão sempre em movimento, significando sempre de muitas e variadas. Sempre as mesmas mas, ao mesmo tempo, sempre outras. (Orlandi, 2011, p. 34)

Dessa maneira, a enunciadora se coloca dentro de uma "ordem do discurso", em que o já-dito vai sendo retomado dentro da especificidade do momento da fala. Em outras palavras, ancorada na história, a narração, a atualização discursiva, contribui para a enunciadora se constituir como sujeito, forma-sujeito, capaz de produzir sentido para possíveis leitores. Ao mesmo tempo em que a enuncia-

aqui, precisaria - no nosso entendimento - ser relida, justamente, porque estamos diante de um corpo negro, pobre e periférico; diferentemente do corpo que ocupa, majoritariamente, a teoria psicanalítica freudiana e lacaniana.

https://periodicos.unifap.br/index.php/letras

Macapá, v. 7, n. I, Io semestre, 2017. 


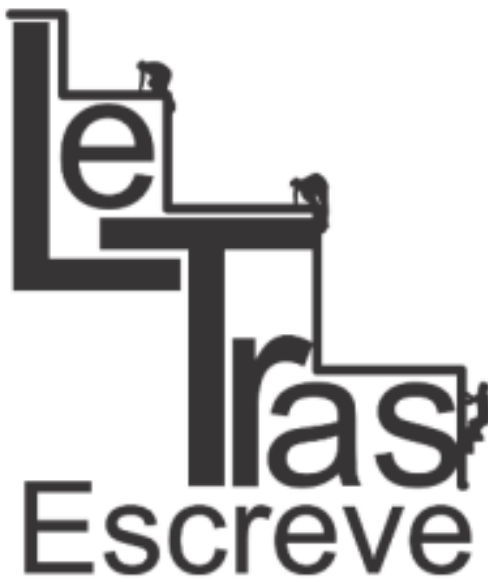

(ISSN 2238-8060) ção poderia se processar de uma outra maneira (tranquila, sem culpa), é a ilusão de que ela não poderia que causa efeitos e que torna os enunciados de Olhos d'água legíveis, nos apresentando uma filha posta em relação de alteridade e identidade com sua mãe, cujos oIhos se esvaecem.

Além disso, um corpo vai sendo lido de maneira a ressaltar um marcante efeito de algo que se perdeu e continua se perdendo: "Sendo a primeira de sete filhas, desde cedo, busquei dar conta de minhas próprias dificuldades, cresci rápido, passando por uma breve adolescência" (Evaristo, 2016, p. 16, grifos nossos). Ao mesmo tempo em que a perda da imagem dos olhos da mãe é ressaltada, a enunciadora mostra como a sua própria vida parece ter sido abreviada, como se os estágios "naturais" da vida fossem sendo diminuídos. Percebamos, agora, que tal problemática só é ressaltada pela intersecção entre gênero, etnia e classe social. Tal banalização do tempo, que contribui para a constituição da enunciadora em sujeito, acaba sendo possível pelos discursos que se atualizam sobre "ser" mulher, negra e pobre.

$\mathrm{Na}$ esteira de Butler (2015), podemos perceber o quanto a enunciação de uma vida, de um "ser", se revela pela violência ética, que seria a imposição de um reconhecimento a partir de um enquadramento prévio no qual alguns corpos são valorizados como dignos da vida ou passiveis de luto. Por isso, segundo a filósofa, deve-se questionar sob quais condições o reconhecimento ocorre; principalmente, deve-se perguntar se o outro é reconhecido mesmo se mantendo irredutivelmente outro. Nisso, um "ethos" violentado vai sendo elaborado pela atualização discursiva, construindo uma relação de subalternidade com diversos outros elementos: a imagem da mãe, o tempo experenciado etc. No entanto, apesar da aparência de unida-

https://periodicos.unifap.br/index.php/letras

Macapá, v. 7, n. I, Io semestre, 2017. 


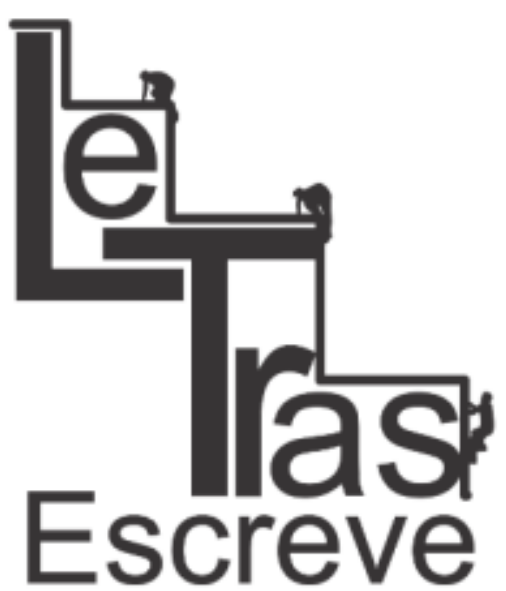

(ISSN 2238-8060) de - pela imagem da filha em culpa - o que temos, na verdade, é uma dispersão "disfarçada" pela própria linguagem, já que a enunciadora se "forma" como sujeito em relação, por exemplo, de alteridade com a mãe, com o já vivido, com outras posições sociais que lhe antecedem discursivamente. Ou seja, no mesmo, temos o outro (nem sempre lidos sob conotações positivas, como o desgaste pelo trabalho mal remunerado, que parece ser o caso da mãe, cujo corpo sofre as marcas físicas disso) mutuamente, dizendo-se reciprocamente. O imaginário e o real, então, vão se apresentado pelo simbólico:

Trata-se de considerar a unidade (imaginária) na dispersão (real): de um lado, a dispersão dos textos e do sujeito; de outro, a unidade do discurso e a identidade do autor. Assim, mesmo se o próprio do discurso e do sujeito é sua incompletude, sua dispersão, e que um texto seja heterogêneo pois pode ser afetado por distintas formações discursivas, diferentes posições do sujeito, ele é regido pela formação do imaginário da unidade, estabelecendo-se uma relação de dominância de uma formação discursiva com outras, na sua constituição. Esse é mais um efeito discursivo regido pelo imaginário, o que Ihe confere uma direção ideológica, uma ancoragem política. (Orlandi, 2011, p. 72)

Dessa forma, o "eu" do discurso vai se apresentando de uma perspectiva em que é lida como princípio de "agrupamento do discurso, como unidade e origem de suas significações, como fulcro de sua coerência" (ibidem, p. 73); no entanto, isso é efeito do jogo entre memória e esquecimento que permite ao sujeito emergir entre as águas dos olhos de sua mãe: "Sempre ao lado de minha mãe aprendi conhecê-la. Decifrava o seu silêncio nas horas de dificuldades, como também sabia reconhecer em seus gestos, prenúncios de possíveis alegrias" (Evaristo, 2016, p. 16).

O silenciamento vai se colocando como necessidade e, con- 


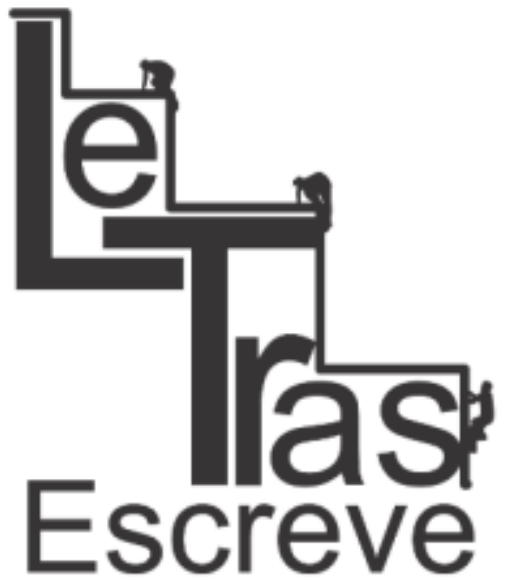

(ISSN 2238-8060)

comitantemente, como imposição à enunciadora que vai tendo seu corpo construído. Necessidade porque o silêncio é constitutivo do dizer, já que a maneira como os enunciados surgem no conto vão ocultando outras possibilidades de falar. Dessa forma, dizer a culpa significa não dizer, por exemplo, a "consciência em paz"; dizer a infância e a adolescência abreviadas significa não dizer fases consideradas típicas nas vidas dos indivíduos "reconhecidos" socialmente. Há imposição porque a censura também atua. Da posição discursiva que vai sendo assumida de subalternidade, feminilidade negra e pobre, a enunciadora se faz possível porque não diz o que poderia dizer, sua liberdade, sua paz, por exemplo. Logo, entre as palavras que vão sendo escolhidas, o silêncio também se faz significar, inscrevendo enfrentamentos e alianças históricas e ideológicas:

\begin{abstract}
Naquele momento, entretanto, me descobria cheia de culpa, por não recordar de que cor seriam os seus olhos. Eu achava tudo muito estranho, pois me lembrava nitidamente de vários detalhes do corpo dela. Da unha encravada do dedo mindinho do pé esquerdo... Da verruga que se perdia no meio da cabeleira crespa e bela... Um dia, brincando de pentear boneca, alegria que a mãe nos dava quando, deixando por uns momentos o lavalava, o passa-passa das roupagens alheias, se tornava uma grande boneca negra para as filhas, descobrimos uma bolinha escondida bem no couro cabeludo ela. Pensamos que fosse carrapato. A mãe cochilava e uma de minhas irmãs aflita, querendo livrar a boneca-mãe daquele padecer, puxou rápido o bichinho. A mãe e nós rimos e rimos e rimos de nosso engano. A mãe riu tanto das lágrimas escorrerem. Mas, de que cor eram os olhos dela? (Evaristo, 2016, p. 16 , grifos nossos)
\end{abstract}

As lembranças do corpo da mãe vão se revelando pelo esquecimento dos olhos da mesma; ao mesmo tempo em que o rememo-

https://periodicos.unifap.br/index.php/letras

Macapá, v. 7, n. I, Io semestre, 2017. 


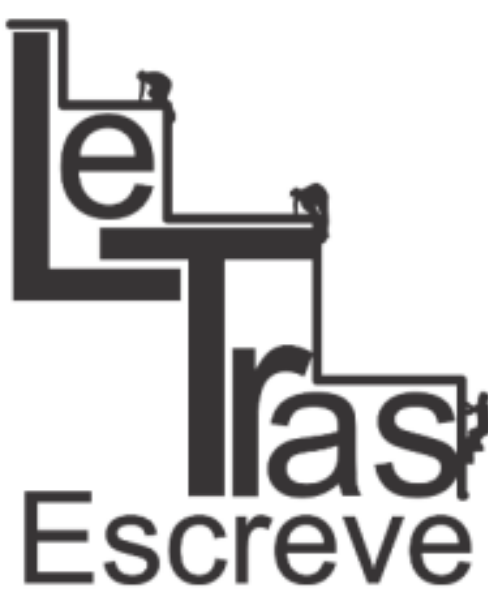

(ISSN 2238-8060) rado se associa a detalhes que remetem a um aparente desleixo estético. No entanto, este é ressignificado pela enunciação assumida como sendo da filha mais velha, na qual "unha encravada", "verruga" e o trabalho com "roupas alheias" assumem a beleza do que não se perdeu, graças, também, à "grande boneca negra", "boneca mãe", com a qual o riso se faz presente. Um riso úmido de lágrimas, mas, nesse caso, de alegria. Nesse momento, rir de felicidade é, ao mesmo tempo, não chorar de tristeza; lembrar das lágrimas de alegria da mãe significa esquecer a cor dos olhos da mesma. Paulatinamente, o corpo da mãe - um corpo negro, feminino e pobre - é construído pela associação com o trabalho e os efeitos dele sobre a aparência da imagem materna.

Mais uma vez, a intersecção se faz presente e necessária inclusive como possibilidade de construção dos corpos da filha e da mãe, de maneira que um permite a leitura do outro por um jogo de espeIhamentos: "A interseccionalidade sugere que, na verdade, nem sempre lidamos com grupos distintos de pessoas e sim com grupos sobrepostos" (Crenshaw, 2004, p. 10). Tal sobreposição é legível também pela construção memorialista do corpo materno - entre permanência e perda - pela "verruga", "unha encravada", mas, também, "boneca negra"; entre pobreza, negritude e ser mulher e criança dentro da sociedade em que se vive.

Com o andar da narrativa, a enunciação se apropria de construções poéticas fortemente marcadas pela sinestesia. Esta figura de linguagem, então, vai se tornando poderoso recurso linguístico para (não) dizer o que se julga recordar. Importante percebemos o quanto a sinestesia, em sua origem etimológica, remete à ideia de "todos os sentidos". Pelo uso dentro da diegese de Olhos d'água, a expansão semântica do termo nos parece inevitável: o "sentido" como signifi-

https://periodicos.unifap.br/index.php/letras

Macapá, v. 7, n. I, Io semestre, 2017. 
cação possível a partir da exploração do que chega aos corpos pela experiência de tato, paladar, visão, olfato e audição. Nesse sentido, são convocados: a audição, pela lembrança das histórias e músicas contadas pela mãe; o cheiro de "coisa nenhuma" que vinha da panela; o contato das mãos com o cabelo crespo; a lembrança visual das lágrimas, mas não da cor dos olhos da mãe; o paladar marcado pela ausência de alimento:

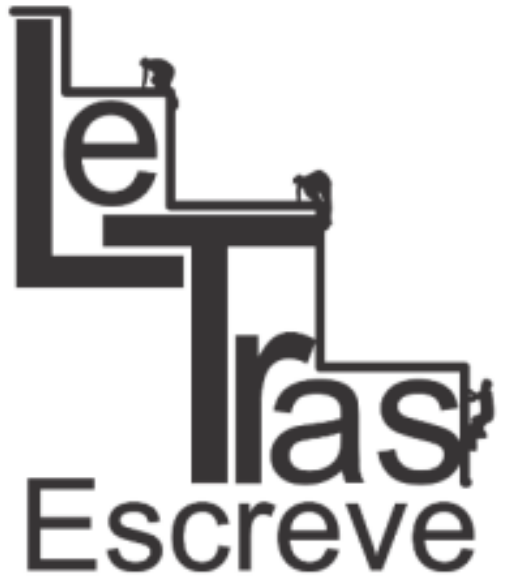

(ISSN 2238-8060)

Ela havia nascido em um lugar perdido no interior de Minas. Ali, as crianças andavam nuas até bem grandinhas. As meninas, assim que os seios começavam a brotar, ganhavam roupas antes dos meninos. Às vezes, as histórias da infância de minha mãe confundiam-se com as de minha própria infância. Lembro-me de que muitas vezes, quando a mãe cozinhava, da panela subia cheiro algum. Era como se cozinhasse ali, apenas o nosso desesperado desejo de alimento. As labaredas, sob a água solitária que fervia na panela cheia de fome, pareciam debochar do vazio do nosso estômago, ignorando nossas bocas infantis em que as línguas brincavam a salivar sonho de comida. E era justamente nos dias de parco ou nenhum alimento que ela mais brincava com as filhas. Nessas ocasiões a brincadeira preferida era aquela em que a mãe era a Senhora, a Rainha. Ela se assentava em seu trono, um pequeno banquinho de madeira. Felizes colhíamos flores cultivadas em um pequeno pedaço de terra que circundava o nosso barraco. Aquelas flores eram depois solenemente distribuídas por seus cabelos, braços e colo. E diante dela fazíamos reverências à Senhora. Postávamos deitadas no chão e batíamos cabeça para a Rainha. Nós, princesas, em volta dela, cantávamos, dançávamos, sorríamos. A mãe só ria, de uma maneira triste e com um sorriso molhado... Mas de que cor eram os olhos de minha mãe? Eu sabia, desde aquela época, que a mãe inventava esse e outros jogos para distrair a nossa fome. E a nossa fome se distraía. (Evaristo, 2016, p. 16-17) 
O recurso poético, acima apontado, em seu funcionamento discursivo, aponta para a importância do lúdico na enunciação. Este, segundo Orlandi (2013, p. 231), forma uma tipologia específica do discurso:

Uma vez que, segundo o que desenvolvemos, o ato de dizer é tipificante, decorre que o funcionamento discursivo se define como atividade estruturante. Assim, tomando como referência o processo, as configurações se estabelecem no (e pelo) ato de dizer. Dada a institucionalização da linguagem, ou seja, o fato de que há um processo de legitimação histórica das suas formas - pois elas são disciplinadas - os tipos de estabelecem como produto dessa institucionalização e se fixam como padrões. Dessa forma, eles entram como tipos nas condições de produção de qualquer discurso: o produto (tipo) se recoloca como processo.

Sendo assim, a perspectiva de Orlandi, citada, nos permite pensar o tipo como um produto que também é um processo: isso significa que ele se estabelece a partir de um dizer, mas também se coloca perpetuamente em movimento pela recepção do leitor. Ou seja, ambas, enunciação e recepção só ocorrem dentro de instituições historicamente consolidas na ideologia, como é o caso da literatura tida como artística, por exemplo. O conto estudado, portanto, é dinâmico, já que ocorre dentro de uma interação; de forma que os sentidos não estão dados, mas são convocados pelos leitores em condições de significação. Assim, o lúdico tende para a polissemia: o funcionamento discursivo estabelece-se dentro das condições de produção, por sua vez, marcadas pela busca de uma memória não pela via autoritária ou polêmica, mas multiplicando possibilidades de sentido, sem que uma seja a definitiva. Dessa forma, o caráter aberto estruturante do conto permanece, coerentemente, com a temática 


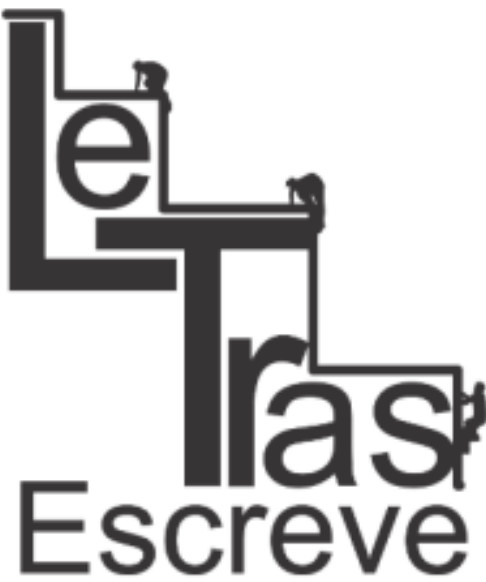

(ISSN 2238-8060)

da lembrança que não ocorre dos olhos da mãe.

A polissemia, o lúdico, então, não pode ocorrer fora do histórico. Por isso, ao longo da estruturação discursiva do conto, temos não somente a memória constitutiva, mas também a institucionalizada, o arquivo. Neste, ocorre "o trabalho social da interpretação onde se separa quem tem e quem não tem direito a ela" (Orlandi, 2011, p. 45). Com isso, a ausência de lembrança dos olhos da mãe soma-se a uma condição social que é de apagamento em diversas camadas. O corpo materno - feminino, negro e pobre - parece perder outras possibilidades de reconhecimento, a não ser pela rememoração da filha. Nesta, não só o aspecto afetivo é resgatado, mas, também, a inscrição histórica e ideológica em que este pode ocorrer. Isso é enfatizado em mais de um momento pela narrativa, uma vez que não se pode sentir nada fora de condições de produção. Estas, por seu turno, promovem significações, mas também apagamento, representado pela memória da cor dos olhos da mãe, perdidos pelo correr de lágrimas. Isso comparece, fortemente, por exemplo, no trecho a seguir:

E naquela noite a pergunta continuava me atormentando. Havia anos que eu estava fora de minha cidade natal. Saíra de minha casa em busca de melhor condição de vida para mim e para minha família: ela e minhas irmãs que tinham ficado para trás. Mas eu nunca esquecera a minha mãe. Reconhecia a importância dela na minha vida, não só dela, mas de minhas tias e todas a mulheres de minha família. E também, já naquela época, eu entoava cantos de louvor a todas nossas ancestrais, que desde a África vinham arando a terra da vida com as suas próprias mãos, palavras e sangue. Não, eu não esqueço essas Senhoras, nossas Yabás, donas de tantas sabedorias. Mas de que cor eram os olhos de minha mãe? (Evaristo, 2016, p. 18, grifos nossos)

https://periodicos.unifap.br/index.php/letras

Macapá, v. 7, n. I, Io semestre, 2017. 
Vejamos, então, que o reconhecimento das mulheres da família, negras e pobres, se dá a partir de uma relação de duplicidade e que se alimenta: por meio do interdiscursivo afetivo; por meio do arquivo que institucionaliza o passado africano somente como passado distante diante do presente marcado pela fuga em busca de trabalho. O risco de perder-se a identidade é tão iminente quando o apagamento a que o corpo materno está sujeito para a filha. Logo, outras formas de maternidade parecem, tristemente, pelo tom do léxico usado, se esvair: as mulheres ancestrais, o continente africano, a sabedoria de outrora, a cidade natal. Nisso, o lúdico atua como tentativa de sobrevivência, já que multiplica e não delimita sentidos:

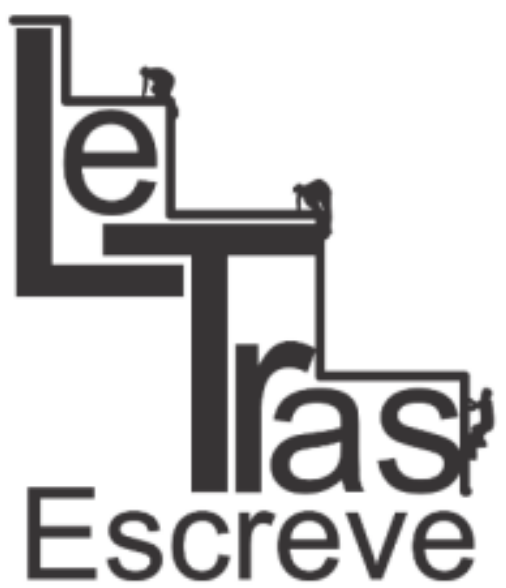

(ISSN 2238-8060)
Às vezes, no final da tarde, antes que a noite tomasse conta do tempo, ela se assentava na soleira da porta e juntas ficávamos contemplando as artes das nuvens no céu. Umas viravam carneirinhos; outras, cachorrinhos; algumas, gigantes adormecidos, e havia aquelas que eram só nuvens, algodão doce. A mãe, então, espichava o braço que ia até o céu, colhia aquela nuvem, repartia em pedacinhos e enfiava rápido na boca de cada uma de nós. Tudo tinha de ser muito rápido, antes que a nuvem derretesse e com ela os nossos sonhos se esvaecessem também. Mas, de que cor eram os olhos de minha mãe? (Evaristo, 2016, p. 17, grifos nossos)

Assim, pela subalternidade enfatizada ao longo do conto, a perda parece iminente. Com isso, outros aspectos do corpo feminino, negro e pobre nem são convocados a estar na narrativa, como a sexualidade, por exemplo, que não chega a ser (re)conhecida pelo arquivo relido pela enunciação. Ao mesmo tempo, a enunciadora, tornada forma-sujeito, não é nem senhora de si nas escolhas que opera nem nas críticas que poderia fazer ao seu não reconhecimento, que reverbera na perda paulatina da imagem do corpo materno.

Até aqui, vai ficando nítida a percepção do funcionamento dis- 


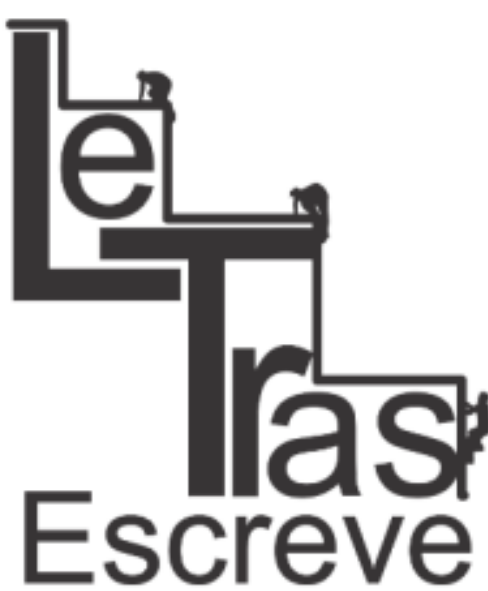

(ISSN 2238-8060) cursivo que se textualiza no conto de Conceição Evaristo (e que, talvez, aponte como indício de leitura para outros textos ficcionais assinados pela autora). Discursos sobre gênero, etnia e classe social vão sendo atualizados a partir de uma enunciadora que se constrói em sujeito em um caminho entre a recuperação e a perda. Mesmo a rememoração, como vimos até aqui, ocorre sob a condição da perda de outras possibilidades de sentido. Isso ocorre dentro de condições de produção que são específicas no que tange ao desenvolvimento da representação das personagens, uma vez que peculiaridades sobre a condição feminina vão se somando às da pobreza e da negritude. Portanto, os corpos se constroem discursivamente em diálogo entre si - a filha tomando dimensão da sua inscrição subjetiva na história a partir da imagem materna, principalmente corporal - ao mesmo tempo em que uma culpa, ideologicamente significada, implica em esquecimentos. Estes são, em parte, percebidos (como a cor dos oIhos da mãe); em parte, ignorados (como o processo histórico e ideológico que leva à possibilidade de rememoração e de enunciação).

Conforme se tenta estabelecer uma recuperação, uma rememoração do corpo materno, inclusive como tentativa de reconquista da imagem do próprio corpo da filha, os significantes vão sendo resgatados, muitas vezes, sem significação fechada:

E foi então que, tomada pelo desespero por não me lembrar de que cor seriam os olhos de minha mãe, naquele momento, resolvi deixar tudo e, no outro dia, voltar à cidade em que nasci. Eu precisava buscar o rosto de minha mãe, fixar o meu olhar no dela, para nunca mais esquecer a cor de seus olhos. E assim fiz. Voltei, aflita, mas satisfeita. Vivia a sensação de estar cumprindo um ritual, em que a oferenda aos Orixás deveria ser descoberta da cor dos olhos de minha mãe. (Evaristo, 2016, p. 18, grifos nossos) 
Como vemos acima, há uma busca que aponta para um deslocamento do olhar do outro, a mãe, para a filha, sem que esta perca aquela "de vista" (jogando com a polissemia aqui também). A recuperação imaginária do corpo materno conjuga-se com uma retomada da inscrição histórica deste, o que fica indiciado pela "oferenda aos Orixás". Dizemos que esta sensação de "recuperar" é imaginária porque, na verdade, ela é imensurável em sua dispersão: lembrar a cor dos olhos da mãe, então, significa assumir um posicionamento discursivo perante a própria inscrição feminina, negra e pobre na história. Aqui, vemos um dos contrastes, por exemplo, com a enunciação construída em "Navio negreiro", já que esta não se dá pela criação de um sujeito que fala identificado ao negro, mas apartado deste, conservando outro posicionamento discursivo, o de dominador, ainda que tenha aparente intenção de denúncia.

Assim, as águas dos olhos da mãe acabam funcionamento ludicamente como textualização do discurso sobre a condição desta mulher; entre a sutileza e a profundidade, lágrimas de alegria e de tristeza que só alguns sabem ler:

E quando, após longos dias de viagem para chegar à minha terra, pude contemplar extasiada os olhos de minha mãe, sabem o que vi? Sabem o que vi? Vi só lágrimas e lágrimas. Entretanto, ela sorria feliz. Mas, eram tantas lágrimas, que eu me perguntei se minha mãe tinha olhos ou rios caudalosos sobre a face? E só então compreendi. Minha mãe trazia, serenamente em si, águas correntezas. Por isso, prantos e prantos a enfeitar o seu rosto. A cor dos olhos de minha mãe era cor de olhos d'água. Águas de Mamãe Oxum! Rios calmos, mas profundos e enganosos para quem contempla a vida apenas pela superfície. Sim, águas de Mamãe Oxum.

Abracei a mãe, encostei meu rosto no dela e pedi proteção. Senti as lágrimas delas se misturarem às minhas. (Evaristo, 2016, p. 18-19) 


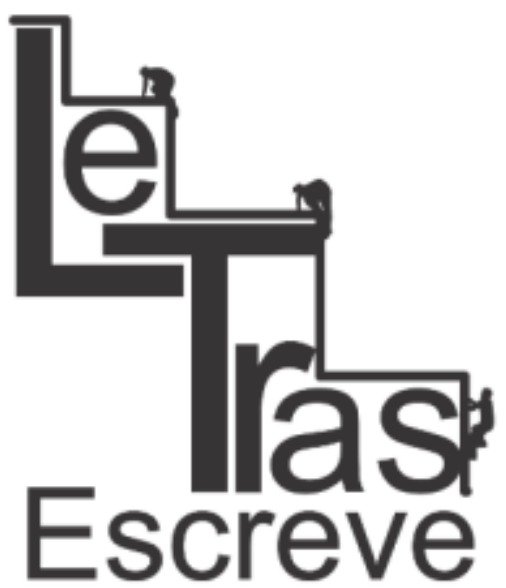

(ISSN 2238-8060)

O encontro das lágrimas maternas com as da filha reflete a aliança corporal e afetiva, mas também as rupturas típicas de uma enunciação que é possível, também, pela atuação do arquivo institucionalizado da violência sobre o corpo negro, que continua gerando seus efeitos discursivos na perda progressiva de origens e lembranças. O discurso lúdico proporciona suavidade à construção narrativa e das personagens, mas também força e violência a uma enunciação desesperada e culpada.

Por fim, as tentativas de elaboração de um corpo que sente a perda iminente e constante não são algo que se finda com o encontro entre filha mais velha e mãe. Pela ação do interdiscurso e do arquivo, os discursos continuarão a se moverem entre os que estão se construindo como sujeitos, compondo uma voz, inscrevendo subjetivamente histórica e ideologicamente. É o que parece acenar para a filha da narradora ${ }^{10}$, a quem caberá a mesma pergunta sem resposta definitiva:

Hoje, quando já alcancei a cor dos olhos de minha mãe, tento descobrir a cor dos olhos de minha filha. Faço a brincadeira em que os olhos de uma são o espelho dos olhos da outra. E um dia desses me surpreendi com um gesto de minha menina. Quando nós duas estávamos nesse doce jogo, ela tocou suavemente o meu rosto, me contemplando intensamente. $E$, enquanto jogava o olhar dela no meu, perguntou baixinho, mas tão baixinho como se fosse uma pergunta para ela mesma, ou como estivesse buscando e encontrando a revelação de um mistério ou de um grande segredo. Eu escutei, quando, sussurrando minha filha falou:

\footnotetext{
${ }^{10}$ Importante não confundirmos narradora e enunciadora. Aquele termo restringe-se mais a uma nomenclatura estruturalista da crítica literária sobre o dispositivo narrativo responsável por apresentar a diegese na relação entre o tempo da fala e o do ocorrido. Já a enunciadora se refere a uma dimensão histórica, social e ideológica da construção de um "eu" que, pela interpelação, consegue falar, mas só porque assume, desde sempre, uma posição diante da realidade. Portanto, são termos, conceitos, que apontam para funcionamentos específicos dentro do estudo que se pretende fazer.
}

https://periodicos.unifap.br/index.php/letras

Macapá, v. 7, n. I, Io semestre, 2017. 
Mãe, qual é a cor tão úmida de seus olhos? (Evaristo, 2016, p. 18-19)

Com isso, o olhar atua como importante elemento de construção imaginária dos sujeitos sobre si e sobre o outro. Tal processo ocorre pela via dupla da revelação e do ocultamento, do ganho e da perda; o qual, na verdade, é a própria condição do sentido. Portanto, a filha responder à sua questão sobre identidade aponta tanto para um processo aberto, quanto para um cheio de angústia: o lúdico, então, participa da atualização discursiva como recurso de tentativa de somatória de significações para corpos femininos, negros e pobres que, pela imposição institucionalizada de valores, acabaram sofrendo a violência ética do corpo que trabalha, sofre e sua, mas pouco sonha com os carneiros de algodão desfeitos em bocas filiais ${ }^{11}$. Para isso, só um final em forma de pergunta como tradução da busca das personagens.

\section{Referências}

BUTLER, Judith. Relatar a si mesmo: crítica da violência ética. Belo Horizonte: Autêntica, 2015.

CRENSHAW, Kimberle W. A intersecionalidade na discriminação de raça e gênero. In: VV.AA. Cruzamento: raça e gênero. Brasília: Unifem, 2004.

DERRIDA, Jacques. A escritura e a diferença. São Paulo: Editora. Perspectiva, 1971.

\footnotetext{
${ }^{11}$ Não podemos nos esquecer do papel pioneiro das mulheres negras e escravizadas no processo de tomada de decisão sobre os corpos subalternos. Muitas delas, por exemplo, praticavam abortos para impedir que seus filhos fossem tornados escravos. Isso é importante porque ajuda na reconsideração de práticas discursivas feministas no arquivo da história brasileira, no que tange às mulheres negras. Para aprofundar esta questão, sugerimos a leitura do artigo "Feminismo negro: para além de um discurso identitário", de Djamila Ribeiro, publicado na Revista Cult, de dezembro de 2016 (número 219).
}

https://periodicos.unifap.br/index.php/letras

Macapá, v. 7, n. I, Io semestre, 2017. 
EVARISTO, C. Olhos d'água. Rio de Janeiro: Pallas, 2016.

GENETTE, G. Discurso da narrativa. Lisboa: Vega. s.d.

HALL, Stuart. A Identidade Cultural na Pós-Modernidade. Porto Alegre, DP\&A Editora, 2006.

ORLANDI, E. P. Análise de Discurso: princípios e procedimentos. Campinas, SP: Pontes, 2001.

. A Linguagem e seu funcionamento: as formas do discurso.

Campinas: Pontes Editora, 2003.

PÊCHEUX, M. Semântica e discurso. Uma crítica à afirmação do óbvio. Tradução Eni Pulcinelli Orlandi [et al.] Campinas: Editora da Unicamp, 1997.

Recebido em 09/02/2017

Aceito em 29/03/2017 